\title{
Modulation of Passive Avoidance in Mice by the 5-HT IA Receptor Agonist Flesinoxan: Comparison with the Benzodiazepine Receptor Agonist Diazepam
}

\author{
Minoru Tsuji', Hiroshi Takeda*,' and Teruhiko Matsumiya' \\ 'Department of Pharmacology and Intractable Diseases Research Center (Division of Drug Research and Development), Tokyo Medical \\ University, Tokyo, Japan
}

\begin{abstract}
The effects of the 5- $\mathrm{HT}_{\text {IA }}$ receptor agonist flesinoxan on passive avoidance in mice were compared with those of the benzodiazepine receptor agonist diazepam. In preliminary experiments, the retention latency to enter a dark compartment in mice subjected to singletraining sessions with 0.6-mA electric foot shocks for 4, 8, or $16 \mathrm{~s}$ slightly increased in all of the test sessions (immediately, $24 \mathrm{~h}$, and I week after the training sessions), but none of these changes were significant. In contrast, mice subjected to double-training sessions with 0.6-mA electric foot shocks for $16 \mathrm{~s}$ showed a significant increase in retention latency in all of the test sessions. Pretreatment with either flesinoxan or diazepam 30 min before the double-training sessions with $0.6-\mathrm{mA}$ electric foot shocks for $16 \mathrm{~s}$ significantly decreased the retention latency in test sessions $24 \mathrm{~h}$ and I week later. In contrast, mice pretreated with flesinoxan $24 \mathrm{~h}$ before the single-training sessions with $0.6-\mathrm{mA}$ electric foot shocks for 4 , 8, or $16 \mathrm{~s}$ showed a significant increase in retention latency in the test sessions $24 \mathrm{~h}$ and/or I week later. Similar enhancements of retention latency in the test sessions $24 \mathrm{~h}$ and/or I week later were observed also in mice pretreated with flesinoxan $24 \mathrm{~h}$ before the double-training sessions. However, in this time interval following injection, pretreatment with diazepam did not affect the retention latency of mice in any of the test sessions. Neither flesinoxan nor diazepam, at the same doses and time intervals used in the passive avoidance study, modified the thresholds for flinching and jumping elicited by electrical stimuli. These results suggest that the activation of 5- $\mathrm{HT}_{\text {IA }}$ receptors, but not benzodiazepine receptors, has a dual effect on the formation of learning and memory for an aversive event that depends on the time interval following receptor activation.
\end{abstract}

Neuropsychopharmacology (2003) 28, 664-674. doi:10.1038/sj.npp. 1300080

Keywords: passive avoidance; 5- $\mathrm{HT}_{\text {IA }}$ receptor; benzodiazepine receptor; learning and memory; stress; mice

\section{INTRODUCTION}

The brain serotonin (5-hydroxytryptamine; 5-HT) system has been implicated in the pathophysiology and treatment of a wide variety of neuropsychiatric disorders (Murphy, 1990; Graeff et al, 1996; Murphy et al, 1999). A heterogeneous family of at least 14 distinct receptor subtypes has been shown to mediate the effect of 5-HT in the central nervous system (Hoyer and Martin, 1997). Among these, 5$\mathrm{HT}_{1 \mathrm{~A}}$ receptors have received particular attention as a possible target for the treatment of affective disorders such as anxiety and depression. In clinical studies, various 5-

\footnotetext{
* Correspondence: Dr H Takeda, Department of Pharmacology, Intractable Diseases Research Center (Division of Drug Research and Development), Tokyo Medical University, 6-I-I Shinjuku, Shinjuku-ku, Tokyo 160-8402, Japan, Tel: +8I 3335 I 614I ext. 327, Fax: +8I 3 335203 |6, E-mail: ht0417@tokyo-med.ac.jp

Received 2 July 2002; revised 18 September 2002; accepted 26 September 2002

Online publication: 3 October 2002 at http: //www.acnp.org/citations/ Npp 100202398
}

$\mathrm{HT}_{1 \mathrm{~A}}$ receptor agonists have shown promising results with regard to anxiety disorder and depression (Olivier et al, 1999). However, there is also some clinical evidence that 5$\mathrm{HT}_{1 \mathrm{~A}}$ receptor agonists might have a different therapeutic spectrum to that of benzodiazepines for the treatment of various types of affective disorders. For example, $5-\mathrm{HT}_{1 \mathrm{~A}}$ receptor agonists have improved generalized anxiety disorder but not panic disorder, although benzodiazepins have been effective in both types of anxiety disorder (Balon $e t$ al, 1990; Dubovsky, 1990; Sheehan et al, 1993). It is thus possible that the emotional effects produced by $5-\mathrm{HT}_{1 \mathrm{~A}}$ receptor agonists might differ qualitatively from those produced by benzodiazepins.

Previously, we obtained data to support the above hypothesis in studies that compared the effects of benzodiazepines with those of $5-\mathrm{HT}_{1 \mathrm{~A}}$ receptor agonists on various emotional states of naive and stressed mice using our automatic hole-board apparatus (Takeda et al, 1998; Tsuji et al, 2000, 2001). In these experiments, we found that benzodiazepines and $5-\mathrm{HT}_{1 \mathrm{~A}}$ receptor agonists produced quite different effects. The most interesting findings were that pretreatment with the $5-\mathrm{HT}_{1 \mathrm{~A}}$ receptor agonists 
flesinoxan and $R(+)$-2-dipropylamino-8-hydroxy-1,2,3,4tetrahydronaphthalene hydrobromide (8-OH-DPAT) but not with the benzodiazepines diazepam and chlordiazepoxide $24 \mathrm{~h}$ before exposure to stress suppressed the decrease in various emotional behaviors produced by acute restraint stress. Several previous behavioral experiments have inspired the interpretation that disappearance of the behavioral response to stress stimuli reflects the development of stress adaptation (Kennett et al, 1985a, b; Ohi et al, 1989). Thus, our findings suggest that $5-\mathrm{HT}_{1 \mathrm{~A}}$ receptor agonists but not benzodiazepines may facilitate some adaptive mechanisms involved in the recognition of and/ or ability to cope with stress stimuli.

Apart from their emotional effects, both $5-\mathrm{HT}_{1 \mathrm{~A}}$ receptor agonists and benzodiazepines affect the learning and memory system. The passive avoidance paradigm has been used to study learning and memory for a stress stimuli. The procedure is based on the innate preference of rodents for the dark compartment of the apparatus, and the suppression of this innate preference following exposure to inescapable shock; that is, passive avoidance performance is an adaptive response to a stressful experience that serves as a measure of learning and memory. Previous studies have demonstrated that various types of $5-\mathrm{HT}_{1 \mathrm{~A}}$ receptor agonists as well as benzodiazepines impair passive avoidance performance (Nabeshima et al, 1990; Rowan et al, 1990; Mendelson et al, 1993; Anglade et al, 1994; Misane et al, 1998; Misane and Ögren, 2000). However, considering the differential effects of $5-\mathrm{HT}_{1 \mathrm{~A}}$ receptor agonists and benzodiazepines on the stress response of mice that have been found in our previous studies (Takeda et al, 1998; Tsuji et al, 2000, 2001), additional detailed investigation should be necessary. Therefore, the present study was designed to further examine the effects of the $5-\mathrm{HT}_{1 \mathrm{~A}}$ receptor agonist flesinoxan and the benzodiazepine receptor agonist diazepam in the formation of learning and memory for stress stimuli using the passive avoidance paradigm.

\section{METHODS}

The present studies were conducted in accordance with the Guide for Care and Use of Laboratory Animals adopted by the Committee on Care and Use of Laboratory Animals of the Tokyo Medical University and the Japanese Pharmacological Society.

\section{Animals}

Male ICR mice (Charles River, Japan) weighing 25-30 g were housed at a room temperature of $22 \pm 1^{\circ} \mathrm{C}$ with a light-dark cycle (light on 6:00 am to 6:00 pm). Food and water were available ad libitum.

\section{Step-Through Passive Avoidance Task}

A two-compartment step-through passive avoidance apparatus (Muromachi Kikai, Japan) was used. The apparatus is divided into bright $\left(10 \times 12 \times 15 \mathrm{~cm}^{3}\right)$ and dark compartments $\left(14 \times 18 \times 15 \mathrm{~cm}^{3}\right)$ by a wall with a guillotine door. The bright compartment was illuminated by a fluorescent light $(8 \mathrm{~W})$. The animals were injected with the test compounds as described below. After a specified time interval following injection, passive avoidance training was performed. Mice were placed in the bright compartment and allowed to explore for $30 \mathrm{~s}$, at which point the guillotine door was raised to allow the mice to enter the dark compartment. When the mice entered the dark compartment, the guillotine door was closed and an electrical foot shock $(0.6 \mathrm{~mA})$ was delivered for 4,8 , or $16 \mathrm{~s}$ (nonshocked control mice were not subjected to electric foot shocks when entering the dark compartment). Training sessions were conducted once (single-training) or twice (doubletrainings) during the light phase (1:00-4:00 pm) of the 12-h day/night cycle. The second double-training session was carried out immediately after first the session. Test sessions were performed immediately, $24 \mathrm{~h}$, or 1 week after training sessions. The mice were placed in the bright compartment and allowed to explore for $30 \mathrm{~s}$, and then the guillotine door was raised. The latency to enter the dark compartment was recorded for up to $300 \mathrm{~s}$. Flesinoxan (0.25-1 mg/kg, i.p.), diazepam (0.25-1 mg/kg, i.p.), or their respective vehicle was administered $30 \mathrm{~min}$ or $24 \mathrm{~h}$ before the start of training sessions. The doses of flesinoxan and diazepam were determined based on our previous findings (Tsuji et al, 2000, 2001).

\section{Pain Threshold}

The dark compartment of the passive avoidance apparatus (Muromachi Kikai, Japan) was used to determine the pain threshold to electrical stimuli. Mice were allowed $15 \mathrm{~min}$ to habituate to the environment of the apparatus before a series of inescapable shocks was delivered. Each series consisted of 10 shocks at the following intensities (mA): $0.01,0.02,0.04,0.06,0.08,0.1,0.2,0.4,0.6$, and 0.8 . The shock duration was $2 \mathrm{~s}$ and the shocks were delivered at 30-s intervals. Thresholds for flinching (forepaws off the grid floor) and jumping (all four paws off the grid floor) were measured.

\section{Drugs}

The drugs used in the present study were flesinoxan hydrochloride (provided by Solvay, The Netherlands) and diazepam (Wako, Japan). Flesinoxan was dissolved in saline. Diazepam was dissolved in Tween 20 until it produced a clear solution, and then diluted with saline to reach the proper concentrations. The final concentration of Tween 20 in the solution was $1 \%$.

\section{Statistical Analysis}

The data are presented as the mean \pm SEM. Student's $t$-test was used to analyze the data from experiments that examined the effects of pretreatment with flesinoxan and diazepam $30 \mathrm{~min}$ before double-training sessions on passive avoidance performance (Figure 2) and the effects of pretreatment with flesinoxan and diazepam on the pain threshold (Figure 7). Other data (Figures 1, 3-6) were analyzed by one-way repeated measures analysis of variance (ANOVA) followed by Dunnett's test. 


\begin{tabular}{|c|c|c|}
\hline$\square$ & Non-stressed & 冈 Stressed (8s) \\
\hline 曰 & Stressed (4s) & Stressed $(16 \mathrm{~s})$ \\
\hline
\end{tabular}
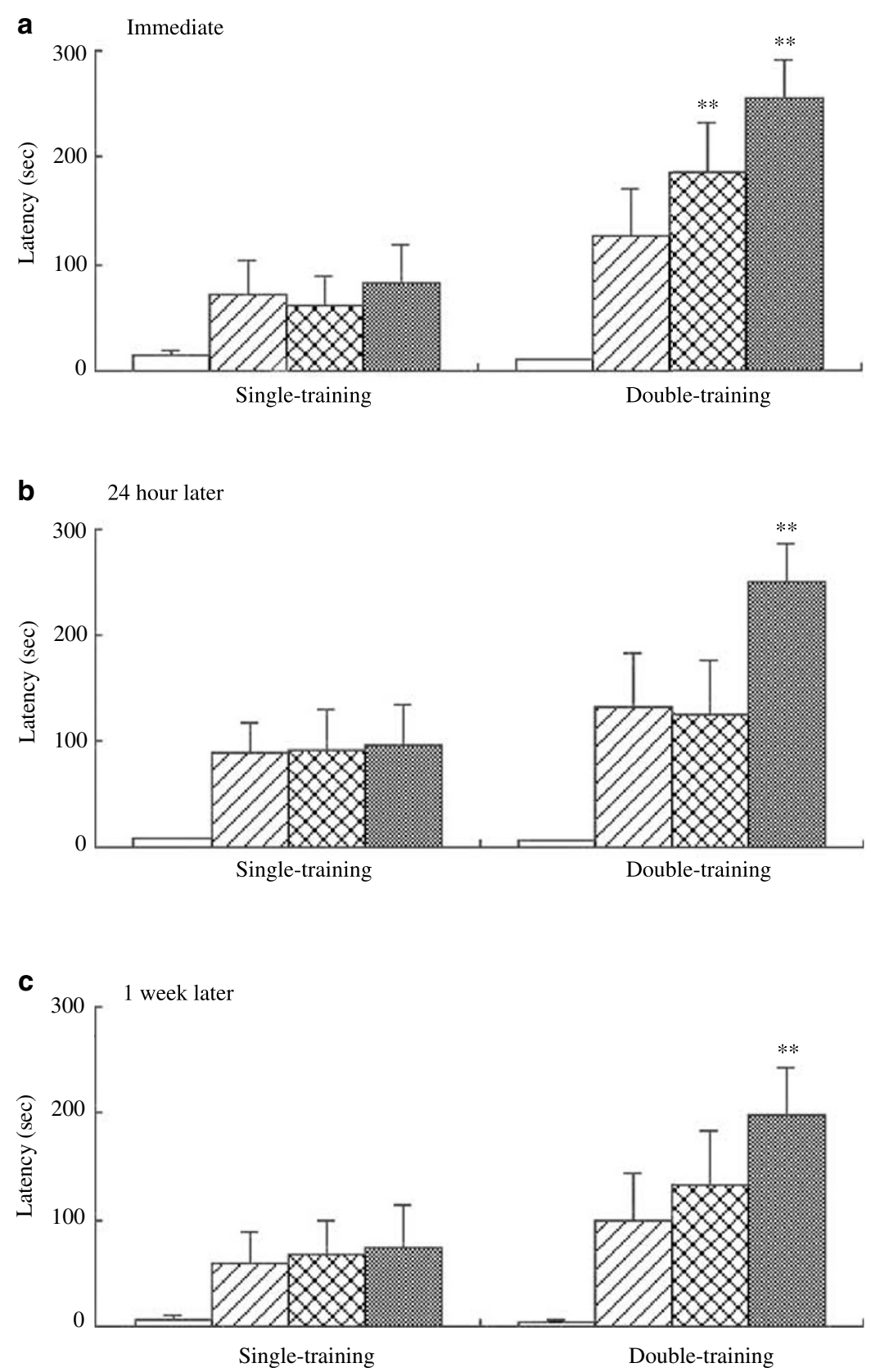

Figure I Passive avoidance performance in mice subjected to the single- or double-training sessions with electrical foot shocks of various durations. Mice were subjected to the single- or double-training session $0.6-\mathrm{mA}$ electrical foot shocks of various durations (4-16 s). Test sessions were performed immediately (a), $24 \mathrm{~h}$ (b), or I week (c) after the training session. Each column represents the mean with SEM of I 0 mice. $* *$ P $<0.01$ vs nonstressed group (open column).

\section{RESULTS}

Passive Avoidance Performance in Mice Subjected to Single- or Double-Training Sessions with Electrical Foot Shocks of Various Durations

Passive avoidance in mice subjected to single- or doubletraining sessions with electrical foot shocks of various durations is shown in Figure 1. The retention latency to enter the dark compartment in mice subjected to singletraining sessions slightly increased in all of the test sessions (immediately, $24 \mathrm{~h}$, and 1 week after the training sessions) as compared with that of nonshocked control mice, but none of these changes were significant. In contrast, the retention latency to enter the dark compartment in mice 
a

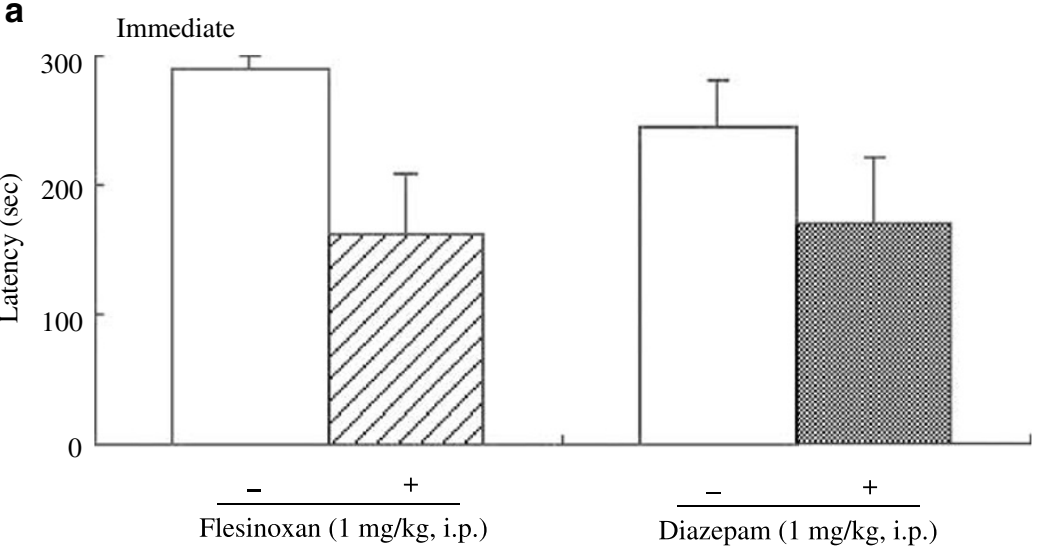

b

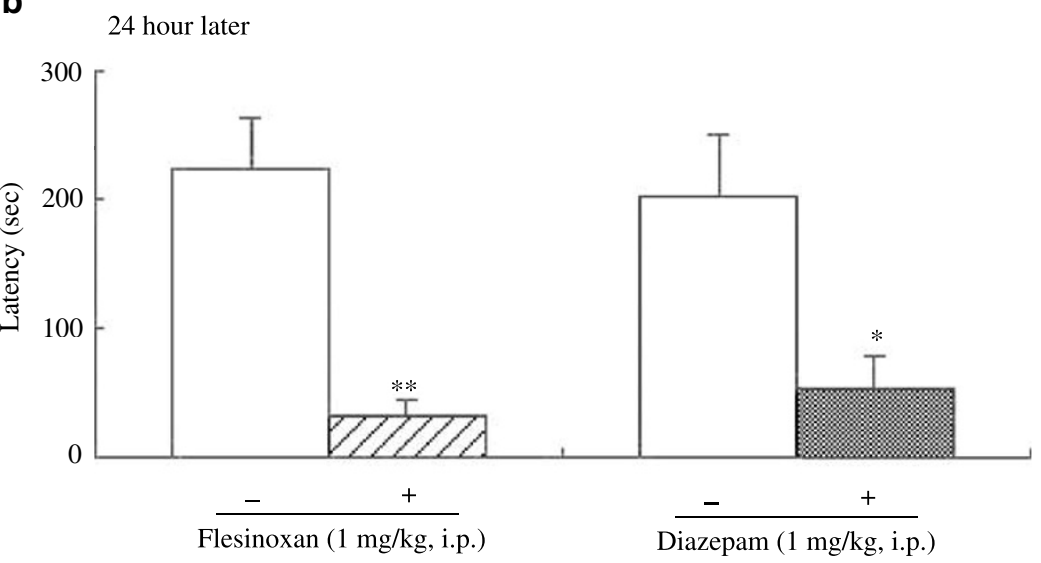

C

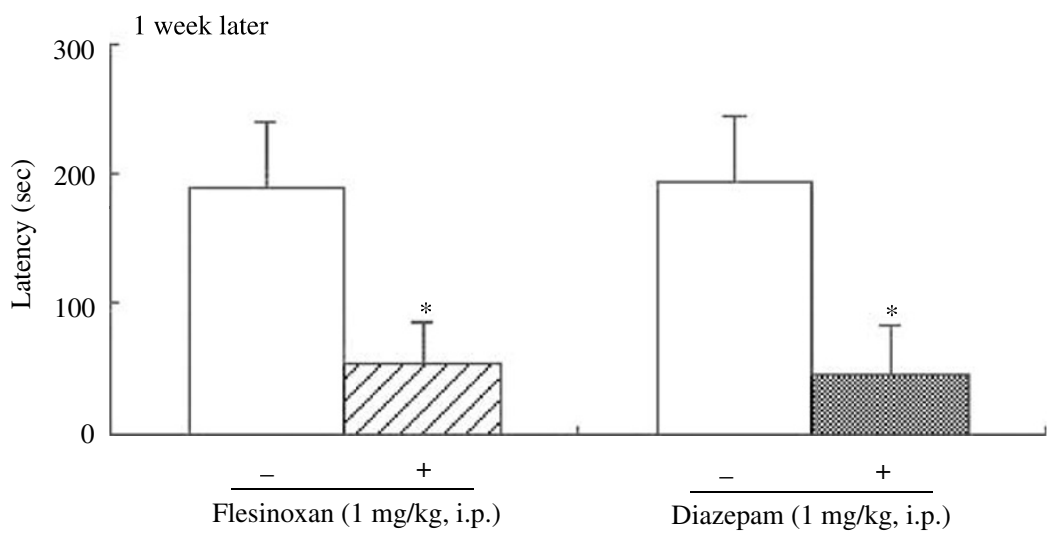

Figure 2 Effects of pretreatment with flesinoxan and diazepam 30 min before the training session on passive avoidance performance in mice. Mice were subjected to the double-training session with a $0.6-\mathrm{mA}$ electrical foot shock of $16 \mathrm{~s}$ duration. Test sessions were performed immediately (a), $24 \mathrm{~h}$ (b), or I week (c) after the training session. Flesinoxan (I mg/ $/ \mathrm{kg}$, i.p.) and diazepam (I mg/kg, s.c.) were administered 30 min before the training session. Each column represents the mean with SEM of eight mice. $* P<0.05$, $* * P<0.0$ I vs vehicle-pretreated group (open column).

subjected to double-training sessions was much higher than that in mice subjected to single-training sessions. The retention latency in mice subjected to $0.6-\mathrm{mA}$ electrical foot shock for $16 \mathrm{~s}$ significantly increased in all of the test sessions as compared with that in nonshocked control mice $(\mathrm{F}(3,36)=8.070, \quad P<0.01 \quad$ immediately; $\mathrm{F}(3,36)=6.135$, $P<0.01$ at $24 \mathrm{~h} ; \mathrm{F}(3,36)=3.998, P<0.05$ at 1 week after the training sessions).
Effects of Pretreatment with Flesinoxan and Diazepam $30 \mathrm{~min}$ before the Double-Training Sessions on Passive Avoidance Performance in Mice

The effects of pretreatment with flesinoxan and diazepam $30 \mathrm{~min}$ before the double-training sessions on passive avoidance performance in mice are shown in Figure 2. In these experiments, mice were subjected to $0.6-\mathrm{mA}$ electrical 


\begin{tabular}{|lll|}
\hline$\square$ Saline & $\bigotimes$ Flesinoxan $(0.5 \mathrm{mg} / \mathrm{kg}$, i.p. $)$ \\
$\square$ Flesinoxan $(0.25 \mathrm{mg} / \mathrm{kg}$, i.p. $)$ & $\square$ & Flesinoxan $(1 \mathrm{mg} / \mathrm{kg}$, i.p. $)$ \\
\hline
\end{tabular}

a

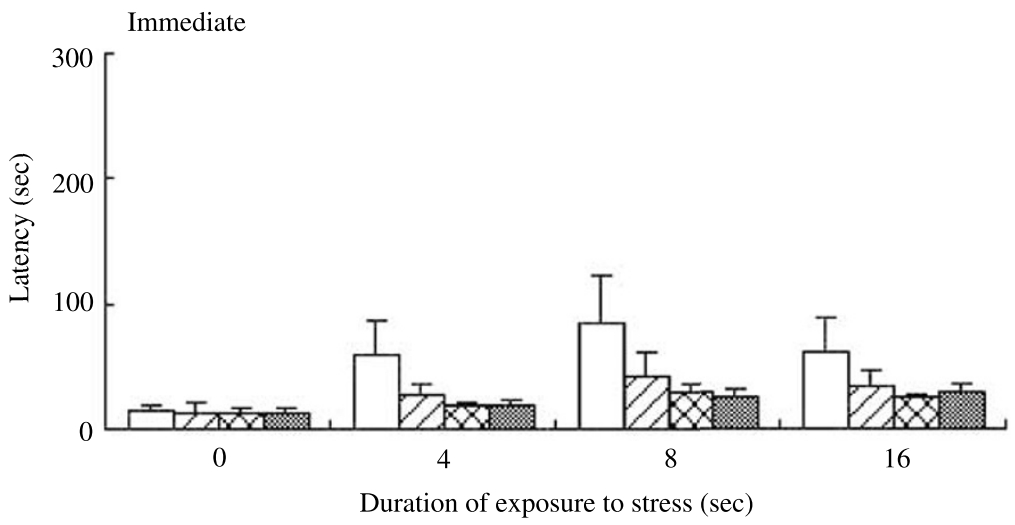

b

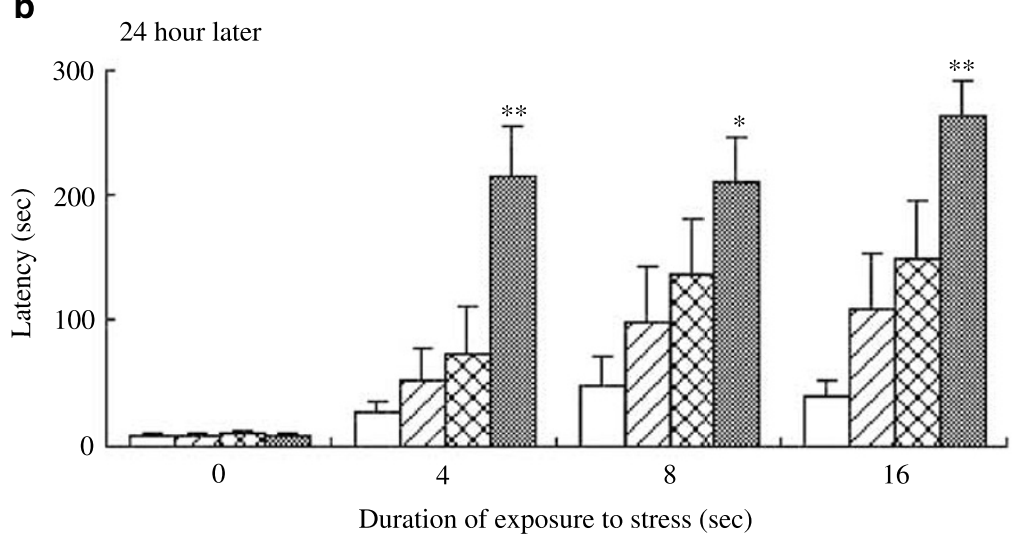

C

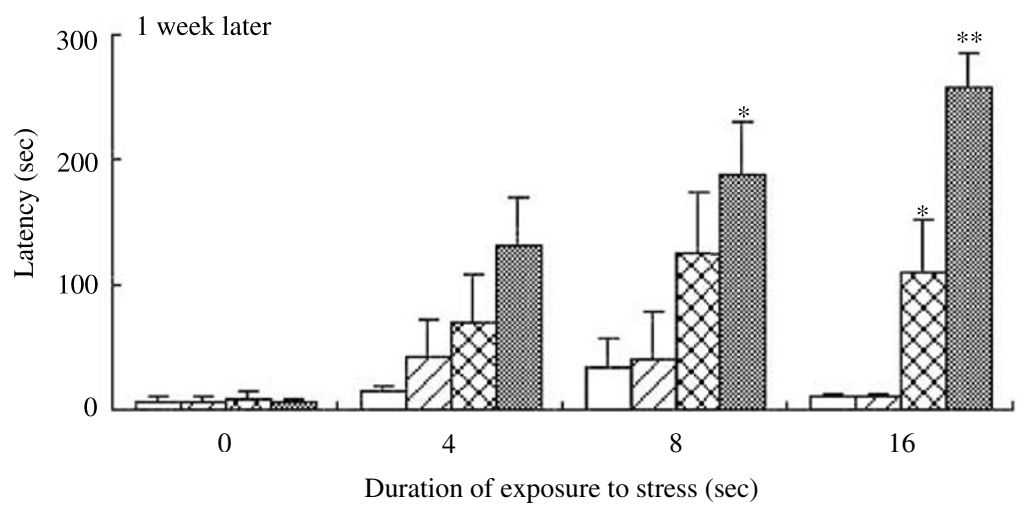

Figure 3 Effects of pretreatment with flesinoxan $24 \mathrm{~h}$ before the single-training session on passive avoidance performance in mice. Mice were subjected to the single-training session with $0.6-\mathrm{mA}$ electrical foot shocks of various durations $(4-16 \mathrm{~s}$ ). Test sessions were performed immediately (a), $24 \mathrm{~h}$ (b), or I week (c) after the training session. Flesinoxan $(0.25-1 \mathrm{mg} / \mathrm{kg}$, i.p.) was administered $24 \mathrm{~h}$ before the training session. Each point represents the mean with SEM of 10 mice. $* P<0.05, * * P<0.01$ vs saline-pretreated group (open column).

foot shocks for $16 \mathrm{~s}$ in the training sessions. As shown in Figure $2 \mathrm{a}$, pretreatment with flesinoxan $(1 \mathrm{mg} / \mathrm{kg}$, i.p. $)$ or diazepam $(1 \mathrm{mg} / \mathrm{kg}$, i.p.) $30 \mathrm{~min}$ before the training sessions slightly decreased the retention latency in the immediate test sessions, but this effect was not statistically significant. Significant decreases in retention latency were observed with flesinoxan at $24 \mathrm{~h}(P<0.01)$ and 1 week $(P<0.05)$ after the training sessions (Figure $2 \mathrm{~b}$ and $\mathrm{c}$ ). Similarly, mice that had been pretreated with diazepam $30 \mathrm{~min}$ before the training sessions also showed a significant decrease in retention latency at $24 \mathrm{~h}$ and 1 week after the training sessions $(P<0.05)$ (Figure $2 \mathrm{~b}$ and $\mathrm{c}$ ). 


\begin{tabular}{|ll|}
\hline$\square$ Saline & $\square$ Flesinoxan $(0.5 \mathrm{mg} / \mathrm{kg}$, i.p. $)$ \\
$\square$ Flesinoxan $(0.25 \mathrm{mg} / \mathrm{kg}$, i.p. $)$ & . Flesinoxan $(1 \mathrm{mg} / \mathrm{kg}$, i.p. $)$ \\
\hline
\end{tabular}

\section{a}

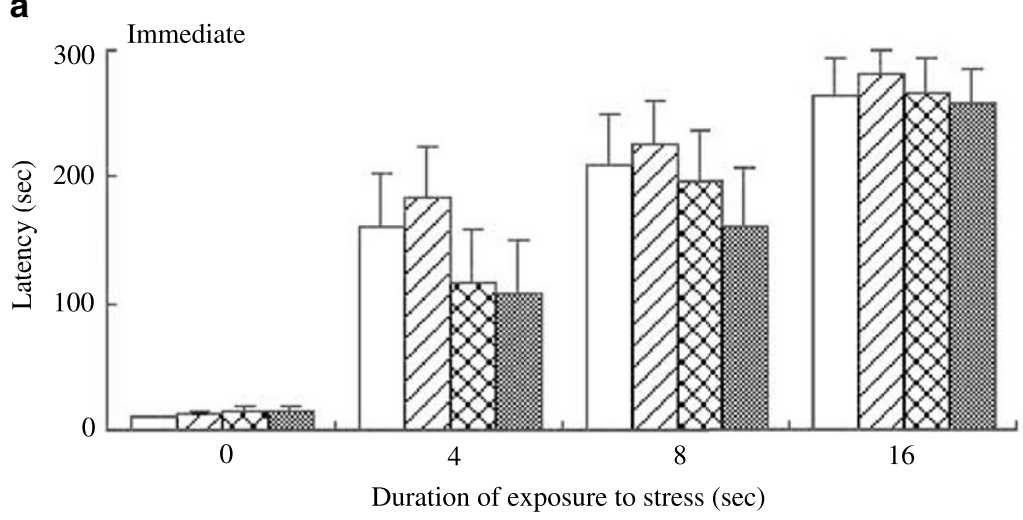

b

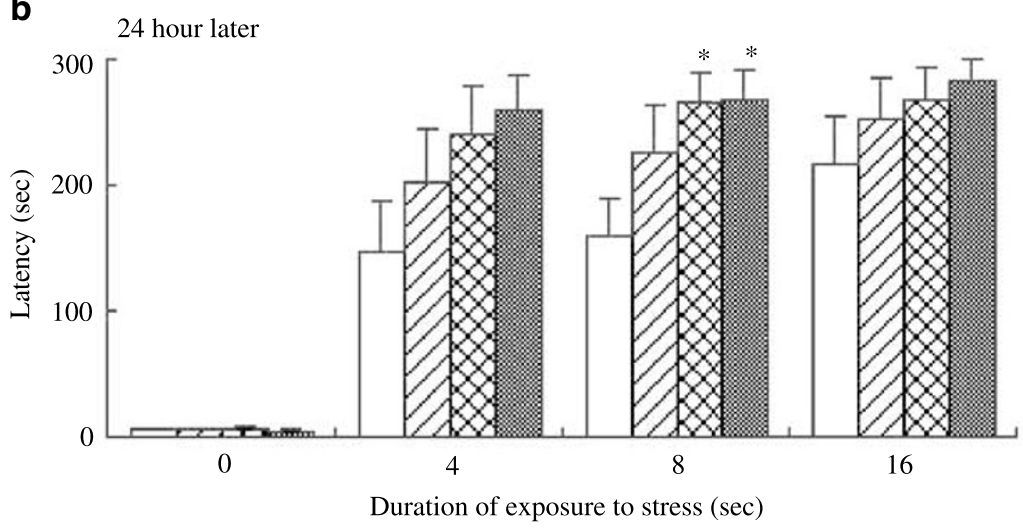

C

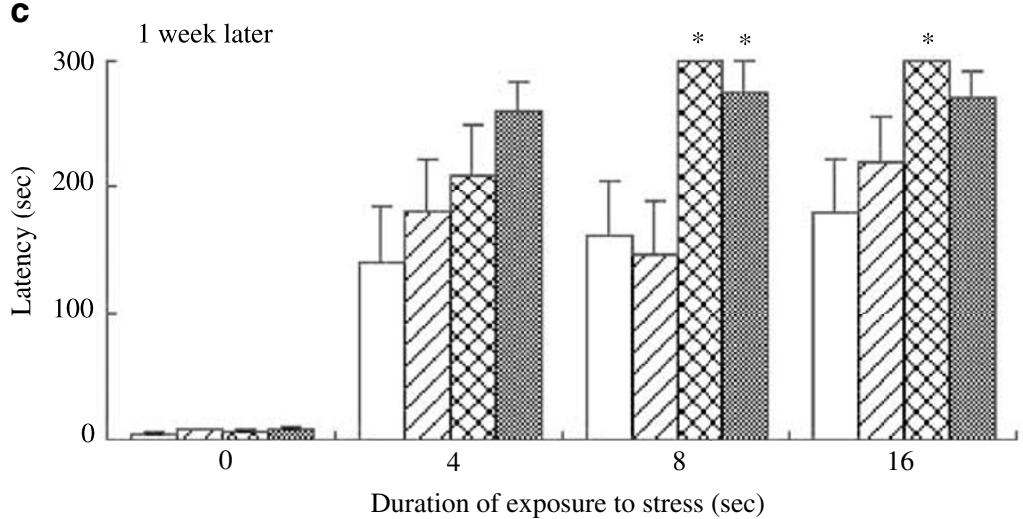

Figure 4 Effects of pretreatment with flesinoxan $24 \mathrm{~h}$ before the double-training session on passive avoidance performance in mice. Mice were subjected to the double-training session with $0.6-\mathrm{mA}$ electrical foot shocks of various durations (4-16 s). Test sessions were performed immediately (a), $24 \mathrm{~h}$ (b), or 1 week (c) after the training session. Flesinoxan $(0.25-1 \mathrm{mg} / \mathrm{kg}$, i.p.) was administered $24 \mathrm{~h}$ before the training session. Each point represents the mean with SEM of 10 mice. $* P<0.05$ vs saline-pretreated group (open column).

Effects of Pretreatment with Flesinoxan $24 \mathrm{~h}$ before the Single- or Double-Training Sessions on Passive Avoidance Performance in Mice

The effects of pretreatment with flesinoxan $24 \mathrm{~h}$ before the single- or double-training sessions on passive avoidance performance in mice are shown in Figures 3 and 4.
Pretreatment with flesinoxan $(0.25-1 \mathrm{mg} / \mathrm{kg}$, i.p. $) 24 \mathrm{~h}$ before single- or double-training sessions did not change the retention latency in the immediate test sessions (Figures 3a and $4 \mathrm{a})$. However, flesinoxan $(1 \mathrm{mg} / \mathrm{kg}$, i.p.)pretreated mice showed a significant increase in retention latency at $24 \mathrm{~h}(\mathrm{~F}(3,36)=7.478, P<0.01$ in the $4 \mathrm{~s}$ stressed group; $F(3,36)=3.253, P<0.05$ in the $8 \mathrm{~s}$ stressed 


\begin{tabular}{|ll|}
\hline Saline & $\bigotimes$ Diazepam $(0.5 \mathrm{mg} / \mathrm{kg}$, i.p. $)$ \\
$\square$ Diazepam (0.25 mg/kg, i.p.) & Diazepam ( $1 \mathrm{mg} / \mathrm{kg}$, i.p. $)$ \\
\hline
\end{tabular}

a

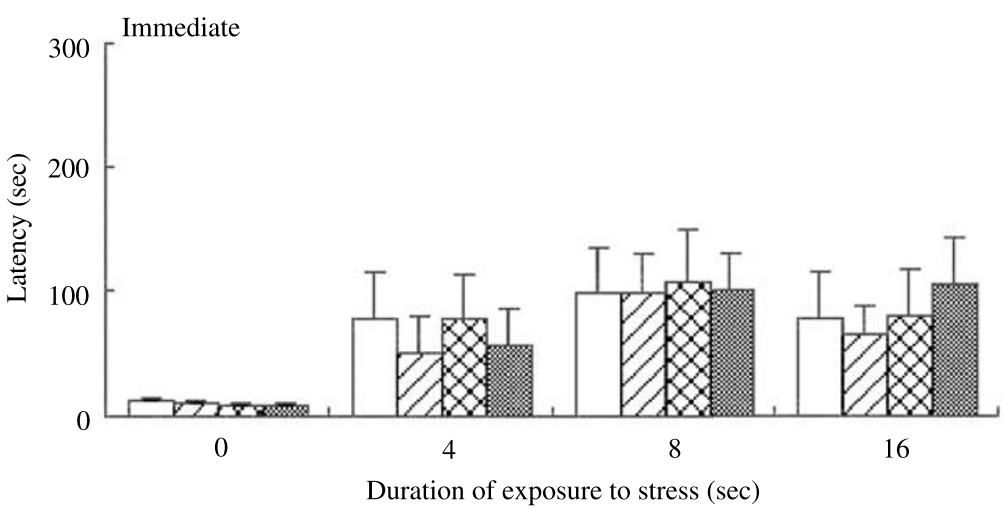

b

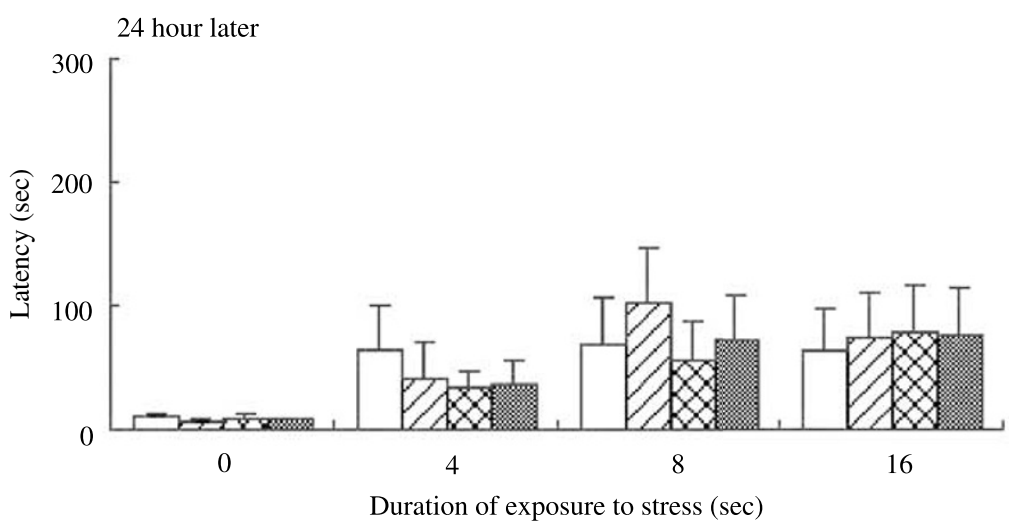

C

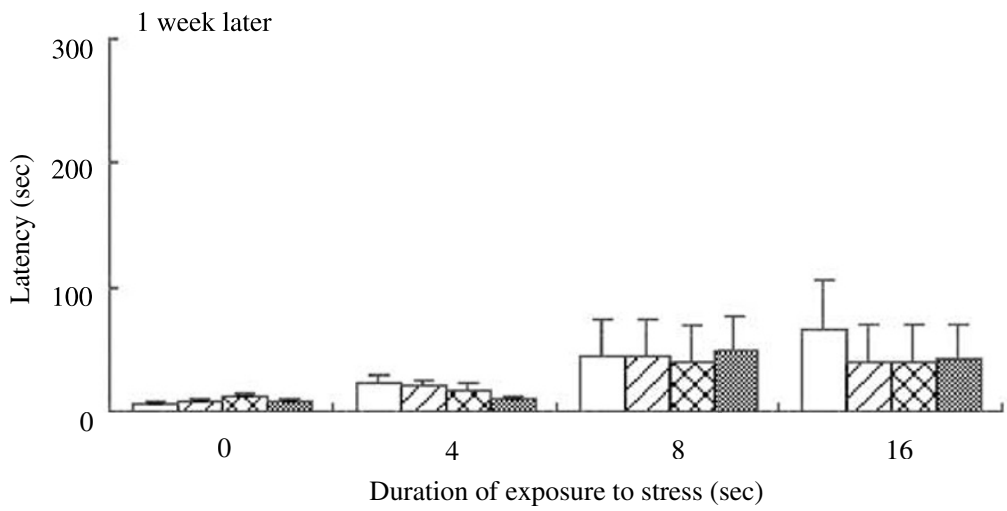

Figure 5 Effects of pretreatment with diazepam $24 \mathrm{~h}$ before the single-training session on passive avoidance performance in mice. Mice were subjected to the single-training session with 0.6-mA electrical foot shocks of various durations (4-16s). Test sessions were performed immediately (a), 24h (b), or I week (c) after the training session. Diazepam $(0.25-1 \mathrm{mg} / \mathrm{kg}$, i.p.) was administered $24 \mathrm{~h}$ before the training session. Each point represents the mean with SEM of 10 mice.

group; $\mathrm{F}(3,36)=7.037, P<0.01$ in the $16 \mathrm{~s}$ stressed group) and/or 1 week $(\mathrm{F}(3,36)=3.964, P<0.01$ in the $8 \mathrm{~s}$ stressed group; $\mathrm{F}(3,36)=20.417, P<0.01$ in the $16 \mathrm{~s}$ stressed group) after the training sessions compared with salinepretreated mice (Figure $3 \mathrm{~b}$ and $\mathrm{c}$ ). Similar enhancements of retention latency in the test sessions $24 \mathrm{~h}(\mathrm{~F}(3,36)=2.925$,
$P<0.05$ in the $8 \mathrm{~s}$ stressed group) and/or 1 week $(\mathrm{F}(3,36)=5.689, \quad P<0.01 \quad$ in $8 \mathrm{~s}$ stressed group; $\mathrm{F}(3,36)=3.100, \quad P<0.05$ in the $16 \mathrm{~s}$ stressed group) later were observed also in mice pretreated with flesinoxan $24 \mathrm{~h}$ before the double-training sessions (Figure $4 \mathrm{~b}$ and $\mathrm{c}$ ). 


\begin{tabular}{|llll|}
\hline$\square$ & Saline & $\bigotimes$ & Diazepam $(0.5 \mathrm{mg} / \mathrm{kg}$, i.p. $)$ \\
乙 & Diazepam $(0.25 \mathrm{mg} / \mathrm{kg}$, i.p. $)$ & $\bigotimes$ & Diazepam $(1 \mathrm{mg} / \mathrm{kg}$, i.p. $)$ \\
\hline
\end{tabular}

a

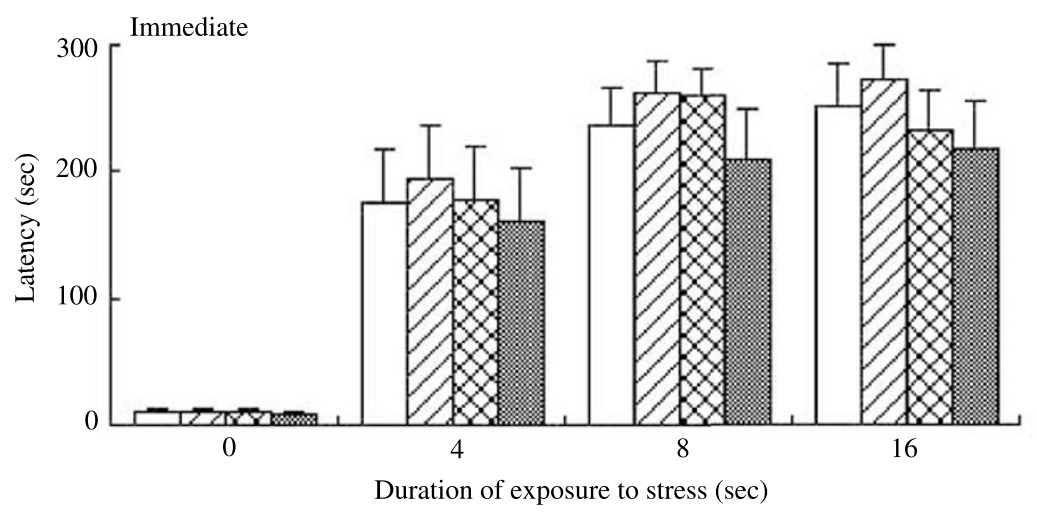

b

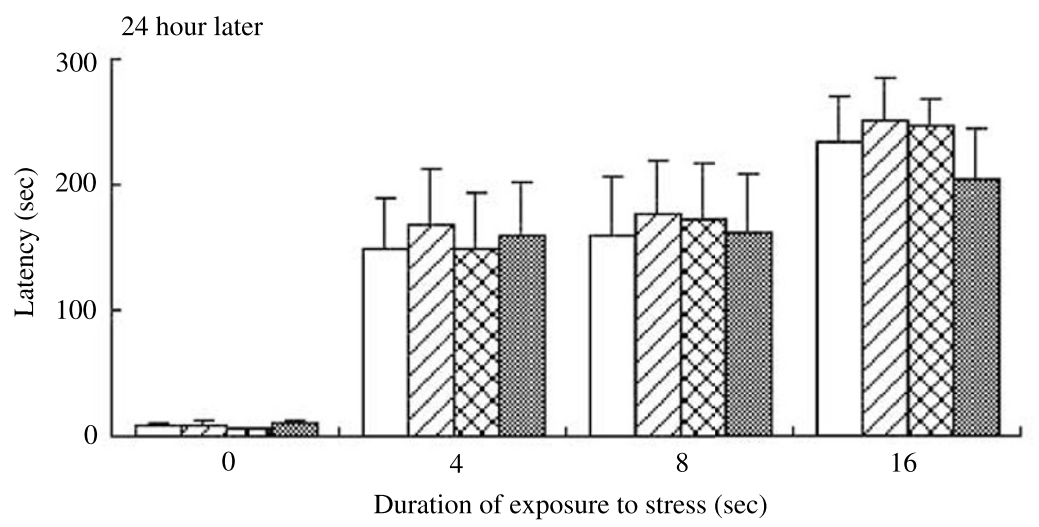

C

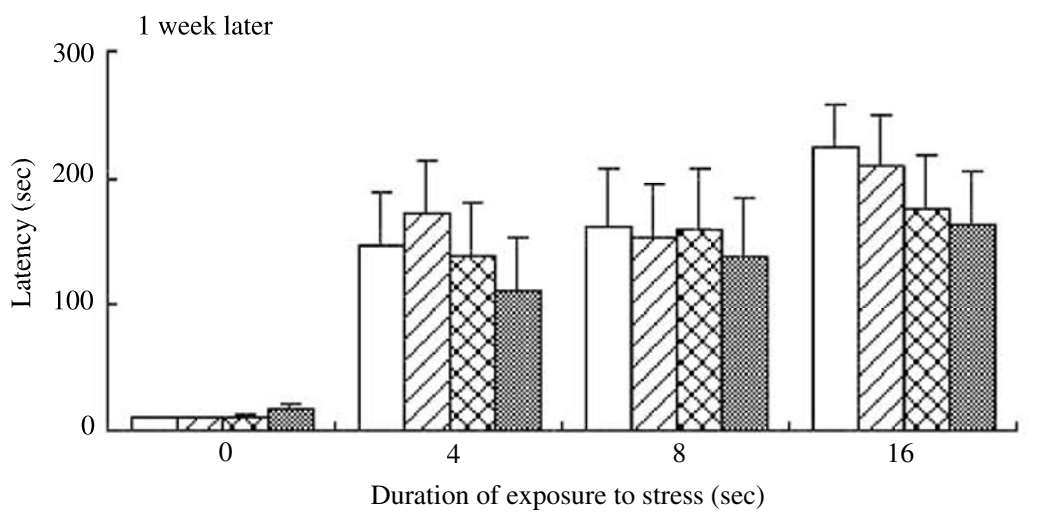

Figure 6 Effects of pretreatment with diazepam $24 \mathrm{~h}$ before the double-training session on passive avoidance performance in mice. Mice were subjected to the double-training session with 0.6-mA electrical foot shocks of various durations (4-16 s). Test sessions were performed immediately (a), $24 \mathrm{~h}$ (b), or I week (c) after the training session. Diazepam $(0.25-1 \mathrm{mg} / \mathrm{kg}$, i.p.) was administered $24 \mathrm{~h}$ before the training session. Each point represents the mean with SEM of 10 mice.

Effects of Pretreatment with Diazepam $24 \mathrm{~h}$ before the Single- or Double-Training Sessions on Passive Avoidance Performance in Mice

The effects of pretreatment with diazepam $24 \mathrm{~h}$ before the single- or double-training sessions on passive avoidance performance in mice are shown in Figures 5 and 6. In contrast to flesinoxan, pretreatment with diazepam $(0.25-1 \mathrm{mg} / \mathrm{kg}$, i.p.) $24 \mathrm{~h}$ before the training sessions did not affect the retention latency in any of the test sessions.

\section{Effects of Pretreatment with Flesinoxan and Diazepam} on the Pain Threshold in Mice

The effects of pretreatment with flesinoxan and diazepam on the pain threshold are shown in Figure 7. Neither 


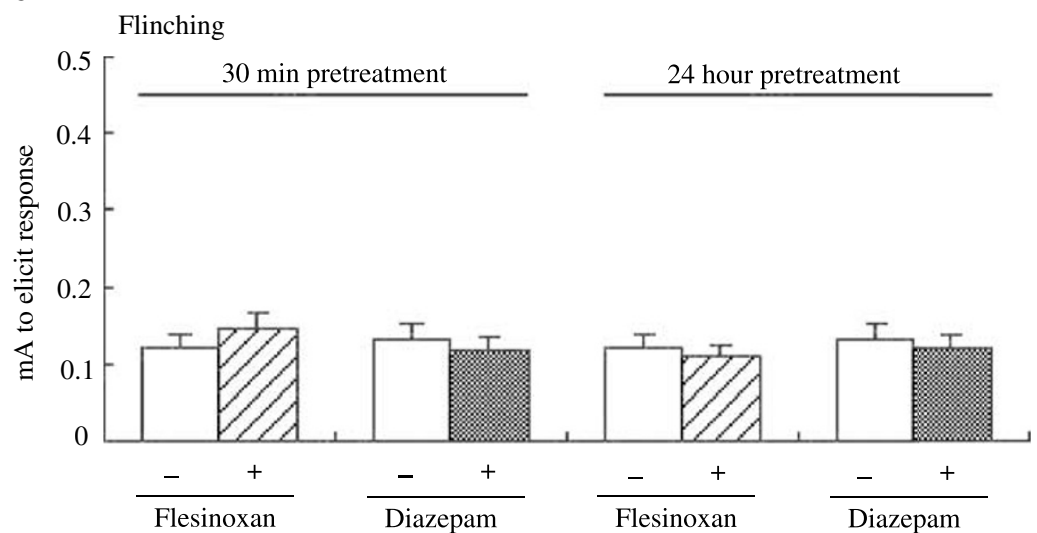

b

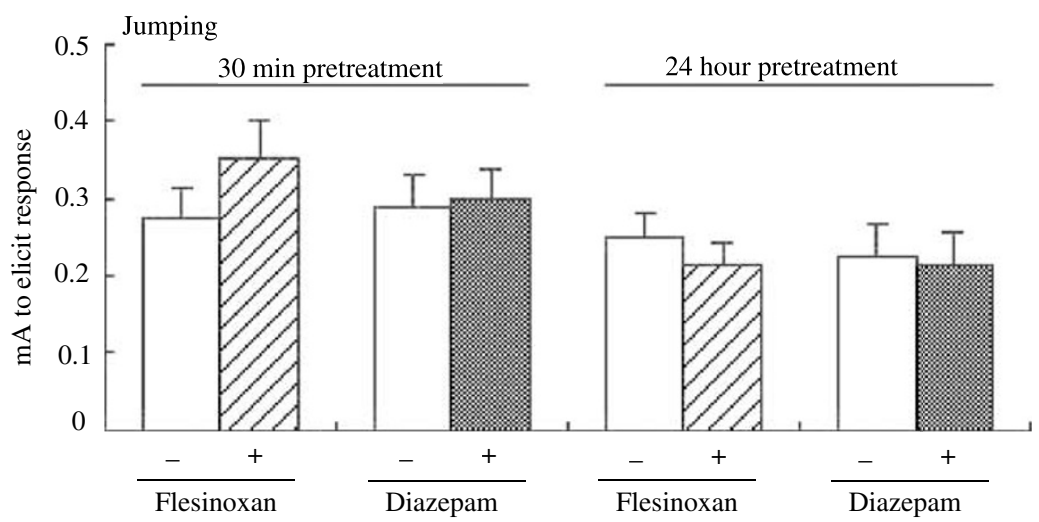

Figure 7 Effects of pretreatment with flesinoxan or diazepam on the pain threshold in mice. Flesinoxan (I mg/kg, i.p.) and diazepam (I mg/kg, i.p.) were administered $30 \mathrm{~min}$ or $24 \mathrm{~h}$ before the delivery of electrical foot shocks. Each column represents the mean with SEM of eight mice.

pretreatment with flesinoxan $(1 \mathrm{mg} / \mathrm{kg}$, i.p.) nor diazepam $(1 \mathrm{mg} / \mathrm{kg}$, i.p.), at the same time intervals used in the passive avoidance study, modified the thresholds for flinching (Figure 7a) and jumping (Figure $7 \mathrm{~b}$ ) elicited by electrical stimuli.

\section{DISCUSSION}

The first experiments in the present study demonstrated that the retention latency to enter the dark compartment in mice subjected to single-training sessions with $0.6-\mathrm{mA}$ electric foot shocks for 4,8 , or $16 \mathrm{~s}$ slightly increased in all of the test sessions (immediate, $24 \mathrm{~h}$, and 1 week after the training session) as compared with that of nonshocked control mice, but none of these changes were significant. These results suggest that mice had partially acquired the task under these conditions. In contrast, mice subjected to double-training sessions with $0.6-\mathrm{mA}$ electric foot shocks for $16 \mathrm{~s}$ showed a significant increase in retention latency in all of the test sessions as compared with that of nonshocked control mice, indicating that mice had completely acquired the task under these conditions. Using these two different experimental conditions, the present study investigated the effects of the $5-\mathrm{HT}_{1 \mathrm{~A}}$ receptor agonist flesinoxan on passive avoidance in mice compared with those of the benzodiazepine anxiolytic diazepam.
The present study demonstrated that pretreatment with either flesinoxan or diazepam $30 \mathrm{~min}$ prior to doubletraining sessions with $0.6-\mathrm{mA}$ electric foot shocks for $16 \mathrm{~s}$ significantly decreased the retention of latency in test sessions $24 \mathrm{~h}$ and 1 week later. These results agree with previous findings by many investigators that various types of $5-\mathrm{HT}_{1 \mathrm{~A}}$ receptor agonists as well as benzodiazepine anxiolytics impair passive avoidance performance (Nabeshima et al, 1990; Rowan et al, 1990; Mendelson et al, 1993; Anglade et al, 1994; Misane et al, 1998; Misane and Ögren, 2000). Therefore, the present findings confirm that the ability of mice to acquire a passive avoidance task is impaired at an early stage (30 min later) after the activation of $5-\mathrm{HT}_{1 \mathrm{~A}}$ as well as benzodiazepine receptors.

On the other hand, the present study also showed that pretreatment of mice with flesinoxan but not diazepam $24 \mathrm{~h}$ before single-training sessions with a $0.6-\mathrm{mA}$ electric foot shock for 4,8 , or 16 s produced a significant increase in the retention latency in test sessions $24 \mathrm{~h}$ and 1 week later. Furthermore, a similar enhancing effect of flesinoxan was observed in mice subjected to double-training sessions. The lack of an effect of pretreatment $24 \mathrm{~h}$ beforehand with flesinoxan on locomotor and/or exploratory behavior of mice has been confirmed in our previous studies (Tsuji et $a l, 2000,2001$ ), indicating that the effects of flesinoxan in the present passive avoidance are not likely nonspecific effects on general motor activity. The present findings 
therefore suggest that the ability of mice to acquire a passive avoidance task is facilitated at a late stage ( $24 \mathrm{~h}$ later) after the activation of $5-\mathrm{HT}_{1 \mathrm{~A}}$ receptors.

To assess whether the effects of drugs on passive avoidance performance are because of nonspecific actions on pain sensitivity, we performed a nociception assay using electric current as the nociceptive stimulus. It is unlikely that changes in pain sensitivity are involved in the effects of drugs on passive avoidance, since neither flesinoxan nor diazepam, at the same doses and time intervals used in the passive avoidance study, modified the thresholds for flinching and jumping elicited by the electrical stimuli.

An important point to explain the present findings may be whether changes in passive performance of mice produced by flesinoxan or diazepam reflect the changes in the emotional sensitivity or the learning and memory process for aversive stimuli. We have previously reported that both substances affected the emotional response of mice for stress stimuli in the hole-board test (Tsuji et al, $2000,2001)$. However, the emotionality that is estimated by the hole-board test is abounding in generality. In contrast, emotionality that affects the passive avoidance task is apparently aversion. Therefore, our previous findings in the hole-board test should not be easily related to the present findings in the passive avoidance test. In the passive avoidance test, it is supposed that, if substances modify the emotional sensitivity of mice to electric foot shocks at the training sessions, the retention latency in the immediate test sessions may be changed as compared with that of vehicle-treated mice. However, we observed that neither flesinoxan nor diazepam affected the retention latency of mice in the immediate test sessions consistently throughout the present study. Based on these results, we suggest that changes in passive avoidance performance of mice produced by flesinoxan or diazepam may be based on changes in the learning and memory process rather than emotional sensitivity for an aversive event. Thus, the present findings suggest that the learning and memory process for an aversive event may be impaired at an early stage after the activation of benzodiazepine receptors. In contrast, the activation of $5-\mathrm{HT}_{1 \mathrm{~A}}$ receptors has a dual effect on the learning and memory process for an aversive event that depends on the time interval following receptor activation.

Our present findings may also be helpful to pave the way for new psychotherapeutic strategies in the clinical realm. For example, exposure therapies are currently used to treat fear anxiety and other intense negative emotions by exposing the patient to the events that create the negative response. The key to the effectiveness of exposure therapies may be to correct the erroneous cognitions for the aversive events (Foa, 2000). The enhancement of acquisition of passive avoidance task observed at a late stage $\left(24 \mathrm{~h}\right.$ later) after the administration of $5-\mathrm{HT}_{1 \mathrm{~A}}$ receptor agonist can be interpreted as the development of the ability to recognize exactly the aversive events. Thus, we here proposed the possibility that adequate activation of 5$\mathrm{HT}_{1 \mathrm{~A}}$ receptors might be useful for some cognitive/ behavioral therapies.

Although the distinct mechanisms of the facilitation of the ability of mice to acquire a passive avoidance task at a late stage ( $24 \mathrm{~h}$ later) after the administration of flesinoxan are unclear, preclinical studies of the pharmacokinetics of flesinoxan have indicated that these drugs disappear from the body within $24 \mathrm{~h}$ after administration (unpublished observation, Solvay Duphar BV, Weesp, The Netherlands). Therefore, under the present conditions, some secondary physiological changes resulting from $5-\mathrm{HT}_{1 \mathrm{~A}}$ receptor activation rather than the effects of residual administered drug may be likely to account for the observed changes in passive avoidance performance. In particular, changes in postsynaptic $5-\mathrm{HT}_{1 \mathrm{~A}}$ receptor function should be notable, since some investigators have suggested that postsynaptic rather than presynaptic $5-\mathrm{HT}_{1 \mathrm{~A}}$ receptors may play a negative role in the modulation of passive avoidance performance (Mendelson et al, 1993; Misane et al, 1998). Functional changes in postsynaptic $5-\mathrm{HT}_{1 \mathrm{~A}}$ receptors under the conditions in the present study have not been clearly defined, but several reports have indicated that postsynaptic $5-\mathrm{HT}_{1 \mathrm{~A}}$ receptors are desensitized $24 \mathrm{~h}$ after a single administration of $5-\mathrm{HT}_{1 \mathrm{~A}}$ receptor agonists (Forster et al, 1994; O'Connell and Curzon, 1996). Thus, it is possible that the desensitization of postsynaptic $5-\mathrm{HT}_{1 \mathrm{~A}}$ receptors might be related to the facilitatory effects of flesinoxan observed in the present study. Otherwise, the involvement of changes in some physiological functions associated with $5-\mathrm{HT}_{1 \mathrm{~A}}$ receptors should also be assumed. For example, brainderived neurotrophic factor (BDNF) has been shown to be involved in the consolidation of passive avoidance task (Rose, 2000). Very recently, we found that pretreatment with flesinoxan significantly increased BDNF mRNA expression in hippocampus and amygdala $24 \mathrm{~h}$ later (unpublished observation). Additionally, it should also be noted that flesinoxan has antagonistic activity for $\alpha_{1}$ adrenoceptors as well as agonistic activity for $5-\mathrm{HT}_{1 \mathrm{~A}}$ receptors (Millan et al, 1994; Koek et al, 1998). There is growing evidence that the increase and decrease in the number and/or function of $\alpha_{1}$-adrenoceptors may be closely related to the enhancement and impairment of passive avoidance performance, respectively (Knauber and Müller, $2000 \mathrm{a}, \mathrm{b})$. It is thus possible that the $\alpha_{1}$-adrenoceptor system might be upregulated $24 \mathrm{~h}$ after the administration of flesinoxan by its antagonistic activity for $\alpha_{1}$-adrenoceptors, and this might play a role in the enhancement of passive avoidance performance.

In conclusion, the present study clearly demonstrated that the activation of $5-\mathrm{HT}_{1 \mathrm{~A}}$ receptors but not benzodiazepine receptors has a dual effect on the passive avoidance performance of mice that depends on the amount of time after receptor activation. In particular, enhancement of the ability of mice to acquire a passive avoidance task at a later stage (24 h later) after $5-\mathrm{HT}_{1 \mathrm{~A}}$ receptor activation should be noted. These results suggest that the activation of $5-\mathrm{HT}_{1 \mathrm{~A}}$ receptors may produce the delayed facilitation of some mechanisms regulating the learning and memory process for an aversive event.

\section{REFERENCES}

Anglade F, Bizot JC, Dodd RH, Baudoin C, Chapouthier G (1994). Opposite effects of cholinergic agents and benzodiazepine receptor ligands in a passive avoidance task in rats. Neurosci Lett 182: 247-250. 
Balon R, Pohl R, Yeragani VK (1990). Biological treatment of anxiety disorders. In Pohl R, Gershon S (eds). Progre. Karger: Basel. pp 284-310.

Dubovsky SL (1990). Geberalized anxiety disorder: new concepts and psychopharmacologic therapies. J Clin Psychiatry 51: 3-10.

Foa EB (2000). Psychosocial treatment of posttraumatic stress disorder. J Clin Psychiatry 61: 43-48.

Forster EA, Cronin SM, Sanford J, Fletcher A (1994). Desensitization of postsynaptic $5-\mathrm{HT}_{1 \mathrm{~A}}$ receptors following single administration of 5- $\mathrm{HT}_{1 \mathrm{~A}}$ ligands. Br J Pharmacol 111: 146P.

Graeff FG, Guimarães FS, De Andrade TGCS, Deakin JFW (1996). Role of 5-HT in stress, anxiety and depression. Pharmacol Biochem Behav 54: 129-141.

Hoyer D, Martin G (1997). 5-HT receptor classification and nomenclature: towards a harmonization with the human genome. Neuropharmacology 36: 419-428.

Kennett GA, Dickinson SL, Curzon G (1985a). Enhancement of some 5-HT-dependent behavioral responses following repeated immobilization in rats. Brain Res 330: 253-263.

Kennett GA, Dickinson SL, Curzon G (1985b). Central serotonergic responses and behavioural adaptation to repeated immobilization: the effect of the corticosterone synthesis inhibitor metyrapone. Eur J Pharmacol 119: 143-152.

Knauber J, Müller WE (2000a). Decreased exploratory activity and impaired passive avoidance behaviour in mice deficient for the $\alpha_{1 \mathrm{~b}}$-adrenoceptor. Eur Neuropsychopharmacol 10: 423-427.

Knauber J, Müller WE (2000b). Subchronic treatment with prazosin improves passive avoidance learning in aged mice: possible relationships to $\alpha_{1}$-receptor up-regulation. J Neural Transm 107: 1413-1426.

Koek W, Patoiseau JF, Assie MB, Cosi C, Kleven MS, DupontPasselaigue E et al (1998). F 11440, a potent, selective, high efficacy $5-\mathrm{HT}_{1 \mathrm{~A}}$ receptor agonist with marked anxiolytic and antidepressant potential. J Pharmacol Exp Ther 287: 266-283.

Mendelson SD, Quartermain D, Francisco T, Shemer A (1993). 5$\mathrm{HT}_{1 \mathrm{~A}}$ receptor agonists induce anterograde amnesia in mice through a postsynaptic mechanism. Eur J Pharmacol 236: 177182.

Millan MJ, Rivet JM, Gobert A, Canton H, Veiga S, Bervoets K (1994). 5- $\mathrm{HT}_{1 \mathrm{~A}}$ receptors and the tail-flick response. VI. Intrinsic alpha- $1_{\mathrm{A}}$-adrenoceptor antagonist properties can mask the actions of 5- $\mathrm{HT}_{1 \mathrm{~A}}$ receptor agonists in the spontaneous tail-flick paradigm. J Pharmacol Exp Ther 269: 121-131.

Misane I, Johansson C, Ögren SO (1998). Analysis of the 5- $\mathrm{HT}_{1 \mathrm{~A}}$ receptor involvement in passive avoidance in the rat. $\mathrm{Br} J$ Pharmacol 125: 499-509.
Misane I, Ögren SO (2000). Multiple 5-HT receptors in passive avoidance: comparative studies of $p$-chloroamphetamine and 8OH-DPAT. Neuropsychopharmacology 22: 168-190.

Murphy DL (1990). Neuropsychiatric disorders and the multiple human brain serotonin receptor subtypes and subsystems. Neuropsychopharmacology 3: 457-471.

Murphy DL, Wichems C, Li Q, Heils A (1999). Molecular manipulations as tools for enhancing our understanding of 5HT neurotransmission. Trends Pharmacol Sci 20: 246-252.

Nabeshima T, Tohyama K, Ichihara K, Kameyama T (1990). Effects of benzodiazepines on passive avoidance response and latent learning in mice: relationship to benzodiazepine receptors and the cholinergic neuronal system. J Pharmacol Exp Ther 255: 789-794.

O'Connell MT, Curzon G (1996). A comparison of the effects of 8 OH-DPAT pretreatment of different behavioural responses to 8OH-DPAT. Eur J Pharmacol 312: 137-143.

Ohi K, Mikuni M, Takahashi K (1989). Stress adaptation and hypersensitivity in 5-HT neuronal systems after repeated foot shock. Pharmacol Biochem Behav 34: 603-608.

Olivier B, Soudijn W, van Wijingaarden I (1999). The 5-HT receptor and its ligands: structure and function. Prog Drug Res 52: 103-165.

Rose SPR (2000). God's organism? The chick as a model system for memory studies. Learn Mem 7: 1-17.

Rowan MJ, Cullen WK, Moulton B (1990). Buspirone impaired of performance of passive avoidance and spatial learning tasks in the rat. Psychopharmacology 100: 393-398.

Sheehan DV, Raj AB, Harnett-Sheehan K, Soto S, Knapp E (1993). The relative efficacy of high-dose buspirone and alprazolam in the treatment of panic disorder: a double-blind placebocontrolled study. Acta Psychiatr Scand 88: 1-11.

Takeda H, Tsuji M, Matsumiya T (1998). Changes in head-dipping behavior in the hole-board test reflect the anxiogenic and/or anxiolytic state in mice. Eur J Pharmacol 350: 21-29.

Tsuji M, Takeda H, Matsumiya T (2000). Different effects of $5-\mathrm{HT}_{1 \mathrm{~A}}$ receptor agonists and benzodiazepine anxiolytics on the emotional state of naïve and stressed mice: a study using the hole-board test. Psychopharmacology 152: 157-166.

Tsuji M, Takeda H, Matsumiya T (2001). Protective effects of 5$\mathrm{HT}_{1 \mathrm{~A}}$ receptor agonists against emotional changes produced by stress stimuli are related to their neuroendocrine effects. $\mathrm{Br} J$ Pharmacol 134: 585-595. 